Prace Literackie LX

Wrocław 2021

https://doi.org/10.19195/0079-4767.60.5

ARKADIUSZ KUREK

ORCID: 0000-0002-5238-7652

X LO im. I.J. Paderewskiego Akademickie w Katowicach

\title{
Izolacja a obóz koncentracyjny. Prolegomena
}

Każdy człowiek ,jako zwierzę stadne" stworzony jest do życia w grupie ludzi, z którymi buduje wspólnotę ${ }^{1}$. Wspólnotą może być dom rodzinny, grono przyjaciół, znajomych z pracy, podwórka czy sąsiadów. Czujemy się lepiej, spotykając się z innymi ludźmi. Dobrze odnajdujemy się w towarzystwie zwierząt, z którymi jesteśmy związani. Ludzie chcą żyć w społeczeństwie, w którym czują się potrzebni. Radość i miłość wypływające z tego rodzaju współistnienia oddziałują na nasze samopoczucie. Czasami, widząc kogoś na ulicy, jesteśmy zainteresowani jego historią życia, kim jest, co sobą reprezentuje. Zdarza się, że spotkanie z kimś wywołuje w nas pozytywne uczucia. Cieszymy się na sam jego widok. Niekiedy też charakter innej osoby może spowodować, że będziemy czuć się źle, będziemy narzekać na innych, tworząc wokół negatywną atmosferę. Wtedy najlepszym sposobem dla każdego z nas wydaje się zamknięcie się w jakimś odosobnieniu, ucieczka od wszystkiego oraz od innych ludzi. Czujemy się wtedy bezpieczni, odprężeni, usatysfakcjonowani własnym życiem. Izolujemy się od innych. Czy taki rodzaj alienacji jest nam właściwie potrzebny? Co skłania współczesnego człowieka do odosobnienia i samotności? Czas pandemii zmusił ostatnio ludzkość do swoistego rodzaju izolacji domowej, na którą nikt nie miał wpływu. Strach przed ciężką chorobą, a nawet śmiercią ograniczył podróże, spotkania towarzyskie i służbowe, wymusił telefoniczny lub e-mailowy kontakt ze znajomymi i rodziną, a także samotne spędzanie świąt. To wszystko mogło sprzyjać pojawianiu się stanów depresyjnych, lękowych, pogorszeniu nastroju. Tylko poprzez wspólnotę jesteśmy w stanie działać solidarnie. To ona umożliwia człowiekowi rozwój i w pewnym sensie nadaje sens życia.

${ }^{1}$ Francuski filozof Jean-Luc Nancy w pracy zatytułowanej Rozdzielona wspólnota namysłowi poddaje pojęcie wspólnoty, której zadaniem jest określenie istoty i ciągłości historycznej danej grupy społecznej. Wspólnota jako zjawisko o charakterze kulturowym ma niezaprzeczalny wpływ na poczucie tożsamości. Zob. J.-L. Nancy, Rozdzielona wspólnota, przeł. M. Gurin, Wrocław 2010. 
Współczesny człowiek, mówiąc o izolacji, myśli jedynie o zamknięciu się $\mathrm{w}$ domu, spokoju, niekontaktowaniu się z rodziną lub wyjeździe w nieznane. W czasach wojennych pojawił się inny typ izolacji — izolacja przymusowa. To ona wyznaczała codzienność życia, zmieniała system wartości ludzi, powodowała odczłowieczenie. Najgorsza była izolacja, której doświadczali więźniowie obozów koncentracyjnych. Wcześniej nikt się nie spodziewał, że można pozbawić innego człowieka wolności bez konkretnego powodu. Masowe łapanki, uliczne egzekucje, plądrowanie domów, głód były dla wielu ogromnym przeżyciem. Często ktoś nie rozumiał, dlaczego właśnie on został złapany, jaką winę ponosił. W czasie wywózki do obozu lękowi oraz swoistej ciekawości towarzyszyło zaskoczenie. Sama nazwa obóz koncentracyjny wywoływała grozę². Wspomina o tym jedna z bohaterek książki Haliny Rusek Koleżanki z Birkenau. Esej o pamiętaniu ${ }^{3}$ :

Oświęcim jest miejscem, w którym ujawniły się w całej pełni skutki systemu opartego na pogardzie i nienawiści. Było to bowiem nie tylko miejsce zagłady, lecz także szczególne laboratorium, gdzie wypróbowywano metody upodlenia, odczłowieczania, których ich kaci uważali za ,podludzi"3.

Więźniowie zadawali sobie pytanie, czy jeszcze kiedykolwiek spotkają się z rodzinami, czy zobaczą miasto, w którym żyli przez wiele lat. Sposób traktowania osób wywożonych do obozów w wagonach towarowych przeznaczonych do transportu zwierząt wywoływał strach. Płacz, prośby o jedzenie, ścisk powodowały panikę. Słysząc nazwę obozu, ludzie myśleli, że będzie to tylko rodzaj więzienia, w którym spędzą parę dni lub miesięcy aż do rozprawy sądowej.

W niniejszym artykule, w którym podejmuję przybliżenie zagadnienia izolacji w obozach koncentracyjnych, opieram się na relacjach świadków. Na podstawie treści zawartych w książkach Przeżyłam Oświęcim Krystyny Żywulskiej, Koleżanki z Birkenau. Esej o pamiętaniu Haliny Rusek oraz Majdanek. 15.0117.05.43 r. Dziennik Jadwigi Ankiewicz, I boję się snów Wandy Półtawskiej można stworzyć listę czynników wpływających na lagrowe odczuwanie odosobnienia, zrekonstruować stan psychiki ofiar faszyzmu. Można także spróbować poznać oznaki izolacji więźnia od najbliższych w warunkach, które skutkowały psychiczną degradacją i fizycznym unicestwieniem. Nie ulega wątpliwości, że wykluczenie więźniów ze wspólnoty ludzi wolnych było sytuacją graniczną. Jak zauważa Anna Pawełczyńska:

${ }^{2}$ W relacji Zeewa Factora czytamy: ,Radio Londyn nadało, że Niemcy wywożą całe pociągi węgierskich Żydów do Oświęcimia. Ja na to: »A co to jest Oświęcim?«. Rundbacken spojrzał mi w oczy mówiąc: »Ty nie wiesz, co to jest Oświęcim?!« [...] On powiedział mi zupełnie spokojnie, lodowato: »To jest to miejsce, dokąd oni biorą Żydów, trują ich gazem i spalają ich ciała«. Zob. L. Sadzikowska, Ludobójstwo w świetle wybranych relacji więźniów obozów koncentracyjnych Auschwitz, Majdanek, Stutthof i Gross-Rosen, „Narracje o Zagładzie” 2020, nr 6, s. 259.

${ }^{3}$ H. Rusek, Koleżanki z Birkenau. Esej o pamiętaniu, Katowice 2019, s. 31. 
Rozumienie sytuacji ostatecznych pozwala odważniej spojrzeć w oczy życiu, śmierci, pozwala też zobaczyć sprawy człowieka na tle historii. Pozwala na to, aby zrozumieć, że zdolność do terroru oraz popełniania zbrodni i zdolność do walki z przemocą kształtują historię kolejnych pokoleń. Różnią się tylko fenomeny psychiczne i historyczne, w jakich ta walka się przejawia ${ }^{4}$.

W artykule chciałbym odnieść się do wspomnień kobiet-więźniarek obozowych. Kobiety w obozie inaczej przeżywały izolację. Były bardziej operatywne. Swoje baraki traktowały jak wspólny dom. Skupiały się między innymi na sprzątaniu, przygotowywaniu wspólnych świąt. Ich rozmowy dotyczyły ogniska rodzinnego. Wykonywały często inne prace niż mężczyźni. Część kobiet była zatrudnionych w przemyśle włókienniczym. Jednak duża grupa kobiet musiała sprostać wymaganiom, jakie im stawiano. Musiały ciężko pracować tak jak mężczyźni. Wiele z nich miało gorzej niż mężczyźni. Chodziły w łachmanach, nawet bez jakichkolwiek butów. Mając mniej sił, szybciej zapadały na zdrowiu i umierały. Współpracując z sobą, były bardziej wytrzymałe niż mężczyźni. Duża grupa kobiet nie umiała sobie poradzić z izolacją, dlatego wpadały w choroby psychiczne. Pomoc współwięźniarek miała na celu wzmocnić ich istnienie w obozie.

Życie kobiet w obozie jest rzadko przedstawiane przez autorów tekstów. Autorzy skupiają się przede wszystkim na roli mężczyzn. Od czasu do czasu pojawiają się informacje pisane przede wszystkim przez kobiety, jak wyglądał obóz z ich perspektywy. Nie można tego pominąć. Inga Iwasiów, zajmując się tym problemem, uważa, że „twierdzenie iż kobiety pozostawały na uboczu wobec konfliktów zbrojnych XX wieku byłoby niedorzeczne"5. Kobiety cierpiały tak samo jak mężczyźni, straciły prawo wyboru. W wielu przypadkach można stwierdzić, że ich cierpienie było straszniejsze, ponieważ odebrano im dzieci oraz godność kobiecą.

Wszystkie zdarzenia opisane w publikacjach Haliny Rusek, Krystyny Żywulskiej, Wandy Półtawskiej i Jadwigi Ankiewicz tworzą ciekawe i jednocześnie wstrząsające studium izolacji, osamotnienia więźnia wśród innych osadzonych. Dziennik, relacja, pamiętnik, esej mają realną historyczną wartość, to znakomite tworzywo o nie tylko ilustracyjnym charakterze. Jest to też wymowna pochwała ludzkiej solidarności, wyróżnienie uczucia miłości i nadziei w totalitarnym systemie. Na podkreślenie zasługuje, że niezwykle ważne w walce o godność, o przetrwanie, w przeciwstawieniu się skutkom zbrodniczej działalności oraz narzuconej izolacji są ludzka jedność i moralność ${ }^{6}$.

Myśląc o roli pamiętników, dzienników oraz wspomnień pisanych w obozie lub w późniejszym czasie, zastanawiamy się nad materialnością. Tego typu przedmioty materialne mają wpływ na życie więźnia, a także na otaczający go

4 A. Pawełczyńska, Wartości a przemoc. Zarys socjologicznej problematyki Oświęcimia, Warszawa 1995, s. 10.

5 I. Iwasiów, Centralna płeć cywila, Kraków 2006, s. 404.

6 Więcej A. Glińska, Moralność więźniów Oświęcimia, „Etyka” 2, 1967, s. 173-230; S. Ryn, S. Kłodziński, Postawy i czyny heroiczne w obozach koncentracyjnych, „Przegląd Lekarski Oświęcim" 1986, nr 1, s. 28-45. 
świat. Jak twierdzi Paweł Rodak ${ }^{7}$, „słowa samego piszącego zmieniają jego sposób postępowania, jego życie, jego postawę wobec świata. Mogą zmieniać także życie osób, które są czytelnikami tego tekstu”. Materialność tekstów oddziałuje na samego czytelnika, który przez zaznajomienie się z tekstem może w różny sposób przeżywać tragedię, jaka rozegrała się w obozach koncentracyjnych. Autorzy, tworząc wspomnienia czy dzienniki, przekazują następnym pokoleniom treści wyjątkowe, mające na celu przybliżenie światu to, co sami przeżyli, przedstawiając fakty oraz sposób zachowania we wszystkich sytuacjach. Czytelnik może nie tylko sobie uzmysłowić, jak faktycznie wyglądało życie w lagrze, lecz też przez takie doświadczenie pobrać naukę, jak zachować się w sytuacjach ekstremalnych w swoim własnym życiu. Autorzy w swoich relacjach chcą za pomocą słowa pojawiającego się w tekstach nadać im ważnego dla nich znaczenia. Zdają sobie doskonale sprawę, że ich dzienniki czy relacje nie będą tylko ich indywidualną sprawą, lecz w przyszłości będą czytane przez obce osoby. Dlatego słowo staje się w tym przypadku najważniejsze. Autorzy, opracowując swoje teksty, starają się przemyśleć każde zdanie, robiąc przy tym skreślenia czy dopisując inne fragmenty. Każdy jednak tekst może podlegać krytyce genetycznej, która pozwala na inną interpretację dzieła. Egodokumenty są pewnego rodzaju „świadectwem czasów”, w których możemy odnaleźć odniesienie do historii — w tym przypadku tragedii obozów koncentracyjnych oraz izolacji więźniów przebywających w nich.

Zdaniem Lucyny Sadzikowskiej oficjalne i nieoficjalne listy więźniów obozu odkrywają ,"świat przeżywany” myśli, uczuć i wartości ${ }^{8}$. W egodokumentach znajdziemy analizę norm społecznych, dążenie do prawdy, wzór obywatela patrioty, opis ideologii nazistowskiej czy organizacji życia codziennego. Informacje wyciągnięte $\mathrm{z}$ listów i wspomnień są istotnym elementem rozszerzającym wiedzę o obozach koncentracyjnych. Egodokumenty to źródła najwyższej wagi, na podstawie których możemy poznać ludzką codzienność oraz emocje jej towarzyszące. Samych listów nie zaliczymy do literatury naukowej, jednakże informacje w nich zawarte ukazują nam dość sporą część okresu wojennego.

\section{Powolne wykluczanie ze społeczeństwa}

Wielu więźniów przed transportem do obozu ratunku i pokrzepienia szukało w krótkiej modlitwie, zawierzeniu boskiemu miłosierdziu. O tym wspomina Krystyna Żywulska: „No dziewczęta, pomódlmy się i spróbujmy zasnąć. Jutro czeka nas daleka i nieprzyjemna podróż"9.

7 P. Rodak, Dziennik osobisty jako praktyka piśmienna: działanie, materialność, tekst, Warszawa 2010, s. 164.

${ }^{8}$ L. Sadzikowska, Listy z lagrów i więzień 1939-1945. Wybrane zagadnienia, Katowice 2019, s. 15.

9 K. Żywulska, Przeżyłam Oświęcim, Warszawa 2004, s. 12. 
Modlitwa sprawiała, że więźniowie odczuwali bliski kontakt z Bogiem, izolacja zaś sprzyjała nawiązaniu mistycznego, intymnego, bardzo bliskiego kontaktu z Najwyższym. Pogłębiona religijność przekładała się na żywą nadzieję, że wszystko dobrze się skończy i uwięzieni będą mogli wrócić do domów.

Część zniewolonych zachęcała innych do śpiewania hymnu i wzmacniania postaw patriotycznych, co miało pobudzić wszystkich do walki o życie swoje i innych ludzi:

Przestawiali na różne tory, kołowali, wreszcie zgrzytnęły szyny i pociąg ruszył. Nie wiem, jak to się stało, że bez porozumienia ze wszystkich kątów rozległo się nagle: Jeszcze Polska nie zginęła $^{10}$.

Pieśni patriotyczne miały wykrzesać wśród uwięzionych ducha walki, chęć pojednania i wspólnoty. Wielu więźniów zmieniło jednak nastawienie, przekraczając bramę lagru. Nacisk i krzyki ze strony oprawców, segregacja ze względu na narodowość, płeć, wiek, zawód sprzyjały powstawaniu rozgoryczenia oraz strachu o własne życie i przyszłość. Część osadzonych kierowano od razu po przyjeździe do komory gazowej. Spotęgowanie odczucia izolacji, swoistego wkroczenia do piekła ${ }^{11}$ następowało zaraz na rampie obozu koncentracyjnego i nasilało się z każdym spędzonym w nim dniem. Składało się na to: zabranie uwięzionym ich własnej odzieży i bielizny, wytatuowanie numerów, obcięcie włosów, odebranie najcenniejszych rzeczy, w tym pamiątek rodzinnych, a także kara chłosty, maltretowanie, rozdzielenie z dziećmi i zabijanie ich, przeprowadzanie selekcji, bestialskie przesłuchania, eksperymenty pseudomedyczne, ograniczanie racji żywnościowych, egzekucje wykonywane przy akompaniamencie orkiestry, palenie zwłok w krematoriach. Każdy z więźniów wyglądał podobnie, niczym się nie wyróżniał, czuł się wyobcowany. Ludzie wykształceni, starając się żyć godnie, pobożni, pomocni innym, nagle zostali odarci z wszystkich wartości, jakie mieli. Próbowano wymusić na nich wyzbycie się norm moralnych, odizolowanie od najbliższych i symboli dziedzictwa kulturowego mogło z kolei skutkować upadkiem człowieczeństwa.

O takim właśnie odczłowieczeniu więźniów wspomina Krystyna Żywulska:

Kłuła mnie właściwie nie w rękę, lecz w serce - tak to czułam. Od tej chwili przestałam być człowiekiem. Przestałam odczuwać, pamiętać. Umarła wolność, mama, przyjaciele, domy, drzewa. Nie miałam już nazwiska, adresu... ${ }^{12}$

W swoim odosobnieniu osadzeni chcieli pamiętać o swej przeszłości - jakimi byli ludźmi, co sobą reprezentowali. Nierzadko wspominali domy rodzinne, rodziców, przyjaciół, zabawy młodzieńcze. Taka ucieczka we wspomnienia pod wpływem izolacji pomagała im przeżyć. Każdy, nawet krótki powrót pamięcią

10 Ibidem, s. 13.

11 Nawiązuję do tytułu publikacji: Wiem, jak wygląda piekło. Alina Dąbrowska w rozmowie z Wiktorem Krajewskim, Warszawa 2019.

12 K. Żywulska, op. cit., s. 16. 
do przeszłości był nadzieją na przyszłość. Skazańcy chcieli powrotu do swojego dawnego życia, chcieli poczuć smak wolności, beztroski, cieszyć się każdą przeżytą chwilą. Zgroza, jaka panowała w obozie, wymuszała na nich jednak zachowania zwierzęce. W pamięci każdego $\mathrm{z}$ więźniów po opuszczeniu obozu zostały z pewnością makabryczne wspomnienia, które przeradzały się w nocne koszmary. Część byłych uwięzionych wspominała później, że nie potrafiła poukładać sobie życia, bojąc się powrotu tragicznych wydarzeń. Ale też więźniowie, którym udało się przetrwać obóz, żyli później w przeświadczeniu, że chociaż w przeszłości walczyli o wszystko, mogą teraz zagwarantować własnym rodzinom godne życie w normalności.

Powtarzalne schematy upodlenia człowieka, jak na przykład: klęczenie przez wiele godzin na ziemi, kary cielesne, długotrwałe apele, praca wyniszczająca organizm, ograniczone racje żywnościowe wzmacniały nienawiść do dręczycieli. Na rodzące się pytanie, kiedy ta walka się skończy, nie było odpowiedzi. W ludziach wywoływało to często chęć szybkiej śmierci, ucieczki od strasznej rzeczywistości. Część więźniów, próbując popełnić samobójstwo, z premedytacją rzucała się na ogrodzenie przewodzące prąd lub też chciała zakończyć własne życie w komorze gazowej. Fragment opisu tragicznej śmierci zamieszcza w swej książce Halina Rusek:

Taki kres swojego życia postanowiła położyć Maria. To właśnie przed ogrodzeniem z drutu kolczastego pod napięciem, otaczającym obóz, znajdowała się strefa śmierci. Jeżeli nie zginęło się od kul, to pewna śmierć następowała po dotknięciu zasieków. Codziennie rano jeden z funkcjonariuszy obchodził ogrodzenie obozowe w Birkenau i zbierał zwłoki — przeważnie samobójców... ${ }^{13}$

Więźniowie nie wytrzymywali psychiczne obozowej codzienności. Widok śmierci, choroby, bezradność nieustannie im towarzyszące, wykończenie organizmu sprzyjały załamywaniu się każdego dnia.

\section{Przyjaźń wołaniem o pomoc}

Ludzie starali się walczyć z samotnością, nawiązując przyjaźnie. Wspomina o tym między innymi Jadwiga Ankiewicz ${ }^{14}$ w swoich pamiętnikach:

Kiedy się wypłakałam, poczułam się rzeczywiście lepiej. Wtedy Pani Wisia powiedziała: ,a teraz pięcioraczku, głowa do góry". Od tej chwili tak bardzo pokochałam Panią Wisię... ${ }^{15}$

Przyjaźnie wielokrotnie ratowały więźniom życie. Samotni i bezradni mogli się zwierzyć swoim koleżankom czy kolegom z kłębiących się w nich obaw,

13 H. Rusek, op. cit, s. 83.

14 Jadwiga Ankiewicz (1926-1944) — łączniczka Szarych Szeregów. Ujęta podczas łapanek w Warszawie 15 stycznia 1943 r. i osadzona w niemieckim obozie koncentracyjnym na Majdanku. Do czasu zwolnienia 17 maja 1943 r. potajemnie pisała pamiętnik. Zginęła przypadkowo na jednej $\mathrm{z}$ warszawskich ulic.

15 J. Ankiewicz, Majdanek. 15.01-17.05.43 r. Dziennik, red. J. Laskowska, Lublin 2020, s. 35. 
porozmawiać na temat codziennych trudności. Wspominali razem przeszłość. W obozie osadzeni pomagali sobie nawzajem, opiekowali się chorymi, często narażali życie, aby móc się spotkać z przyjacielem w szpitalu „rewirze”, zanieść mu trochę jedzenia lub picia. Traktowali swoich przyjaciół jak rodzeństwo, a nawet jak rodzinę. Nie była istotna dla nich różnica wieku. Każdy z więźniów potrzebował osoby bliskiej. To ona wzmacniała, dawała namiastkę normalności, była ucieczką od osamotnienia. Pięknie wspomina o tym Wanda Półtawska, która pomagała swojej chorej przyjaciółce w szpitalu, a także sama potrzebowała pomocy innych i na nich się nie zawiodła:

Największą troską już operowanych było ulżyć następnym „królikom”, które leżały nieprzytomne. Pamiętając też, jak same głodowałyśmy w gorączce — nie mogąc łykać wstrętnej zupy, która i dla zdrowych nie była jadalna — potrafiłyśmy zorganizować pomoc z kuchni ${ }^{16}$.

Przyjaźnie przetrwały także po wojnie, gdy więźniowie spotykali się na zjazdach tych, którzy przeżyli obóz oraz kontaktowali się osobiście lub listownie, wspominając czasy wojenne, wymieniając się swoimi troskami i przeżyciami. Były to przyjaźnie na całe życie, nie zawsze łatwe, lecz mające wspólny wątek - cierpienie i izolację wojenną. Wspomina o nich Halina Rusek w Koleżanki $z$ Birkenau $^{17}$.

Na podstawie zawartych w tekstach listów i wspomnień czytelnik poznaje losy całych rodzin. Opisywanie swojego życia na wolności niejednokrotnie sprawia więźniom ból, tworzą wyimaginowane historie na temat swoich rodzin. We wspomnieniach ukazane są stosunki rodzinne, znajomi, przedstawiono też walki żołnierzy w regionie. Listy i paczki od bliskich dają osadzonym nadzieję na szybki powrót do domu, na spotkania z najważniejszymi dla nich członkami rodzin. Należy zauważyć, że obóz koncentracyjny staje się dla więźniów małą ojczyzną ${ }^{18}$, jak określa to Lucyna Sadzikowska. W tej ojczyźnie ukazane są emocje. Więźniowie starają się usystematyzować swoje życie. Nie mają możliwości rozwoju, ale o ile to możliwe, starają się utrzymać baraki w czystości, porządkować prycze, w prosty sposób czasami przygotowują wspólne posiłki czy spędzają razem czas, tworząc nawet sztuki teatralne, śpiewając przy tym napisane przez nich samych piosenki oraz czytając wiersze. Jest to przejaw kultury, która nie została wytępiona z osadzonych.

\section{„Ulepszanie” życia w lagrach}

Uroczystości, które organizowano w lagrze, były dla więźniów namiastką wolności. Rodzinna atmosfera, tańce oraz towarzyszące temu życie kultural-

16 W. Półtawska, I boję się snów, Częstochowa 1998, s. 105.

17 Halina Rusek - polska socjolog, dr hab. nauk humanistycznych, profesor zwyczajny Instytutu Etnologii i Antropologii Kulturowej Uniwersytetu Śląskiego w Katowicach.

18 L. Sadzikowska, Listy z lagrów..., s. 21. 
ne ukazywały życie w obozie z innej perspektywy — tej lepszej. Lecz była to tylko chwila $\mathrm{w}$ walce o przeżycie. W lagrze przebywali poeci, pisarze, ludzie różnych zawodów, którzy potrafili umilić czas innym więźniom. Czasami pozwalano na zabawy, ale i te niekiedy kończyły się tragicznie. Można powiedzieć, że zbrodniarze w ten sposób chcieli pokazać się w pozytywnym świetle. Zabawy, które miały uśmierzyć ból i codzienne cierpienia, często były pozorne - więźniowie nie zapominali przecież, że nieopodal stało krematorium, w którym palono tysiące ludzi. Wielu udawało jedynie, że się bawi, ponieważ tan naprawdę wszystko to budziło bolesne wspomnienia z minionych lat młodzieńczych, utraconej wolności.

Podczas pobytu w obozie próba uczczenia świąt Bożego Narodzenia oraz szczególne uczucia związane nadejściem nowego roku były ucieczką od myśli o tym, co teraz dzieje się w domach rodzinnych, jak ich rodziny spędzają ten świąteczny czas. Osadzeni, śpiewając kolędy, składając sobie życzenia, powracali pamięcią do domowych chwil. Jadwiga Ankiewicz wspomina:

Z okazji tego święta nie przywieźli nam nawet śniadania. Złożyłyśmy sobie ogólne życzenia, panna Schmitówna ${ }^{19}$ odmówiła mszę św., potem zaintonowała: Wesoly nam dzień dziś nastal ${ }^{20}$, wszyscy podjęli za nią. Nie mogłam dłużej wytrzymać i rozbeczałam się. Co tam teraz w domu? ${ }^{21}$

Skazańcy dręczyli się myślami o swoich rodzinach, o tych, których pozostawili — czy jeszcze żyją, w jaki sposób sobie radzą. Niestety nie otrzymywali żadnych informacji o swoich bliskich. Jedyną możliwością kontaktu były listy pisane w języku niemieckim. Lagrowcy znający ten język byli uprzywilejowani, ponieważ szybciej i łatwiej mogli wysyłać ocenzurowane wiadomości do swoich rodzin. Często jedynym kontaktem ze światem zewnętrznym były paczki żywnościowe, na które więźniowie czekali. Były one dla nich bardzo cenne jako oznaki bliskości z rodziną. Krystyna Żywulska wspomina:

Biorę paczkę. Poznaję charakter pisma kogoś drogiego, bliskiego, a odległego teraz o tysiące mil. Zaczynam więc szukać w pudle i znajduję fotografię matki. Jej dobre oczy patrzą na mnie żałośnie, prosząco, tak jakby mówiły: „Żyj! Musisz dla mnie żyć!”22.

W taki sposób każdy z więźniów mógł otrzymać rodzaj grypsu z informacją o rodzinie. Rzeczy znalezione w paczkach były traktowane jak świętość. Nie można było ich ruszać. Dzięki nim izolacja stawała się łatwiejsza do zniesienia. Dotknięcie rodzinnej chustki czy zdjęcia pomagało przeżyć, sprawiało, że życie w obozie stawało się znośniejsze, dawało nadzieję. Wtedy to więźniowie otwierali się chętnie, opowiadali o swojej przeszłości, analizowali własne życie,

19 Jedna z sióstr: Ludmiła, Zuzanna lub Teodora Schmidt — więźniarek w obozie na Majdanku.

20 Wesoly nam dzień dziś nastat — pieśń powstała w XIX wieku, zapisana w śpiewniku księdza Michała Marcina Mioduszewskiego.

21 J. Ankiewicz, op. cit., s. 35.

22 K. Żywulska, op. cit., s. 166. 
marzyli o przyszłości. Niestety tego typu przeżycia, wzbudzające silne emocje, skutkowały też później załamaniem nerwowym, depresją i innymi psychicznymi powikłaniami, z których osadzonym ciężko było potem się otrząsnąć. Pomoc współwięźniów nie zawsze ratowała im życie.

\section{Codzienność w lagrze}

Załamanie nerwowe, zadręczanie się pesymistycznymi myślami, a w końcu apatia i alienacja sprawiały ból nie tylko danej osobie, lecz także innym współwięźniom. Takie osoby przestawały wykonywać swoje lagrowe obowiązki, odmawiały pójścia do pracy, nie chciały przyjmować pożywienia. Śmierć była ich zdaniem jedynym ratunkiem. Prześladowcy, widząc, co dzieje się w barakach, prowadzili osoby chore do krematorium lub rozstrzeliwali je na miejscu. Szok spowodowany krzywdzeniem osamotnionych i udręczonych ludzi wzmacniał w jakiś sposób innych, ale też załamywał słabych psychicznie.

Ucieczką od ciężkich warunków obozowego życia była całodzienna praca poza lagrem. Więźniowie specjalnie zgłaszali się do ciężkiej pracy w polu, przy kopaniu dołów, aby nie widzieć tego, co dzieje się w obozie, w pewien sposób oderwać się, wyrwać choć na chwilę. Halina Rusek stwierdza:

Niewolniczą pracę więźniowie wykonywali na terenie obozu i poza nim. Od końca marca 1942 roku czas pracy wynosił 11 godzin, ale latem był wydłużony i skracany zimą... ${ }^{23}$

Praca powodowała, że skazani bardziej się do siebie zbliżali, lepiej się poznawali, pomagali sobie wzajemnie, gdy ktoś zasłabł. Czasami też nadzór więzienny współdziałał z więźniami. Niektórzy z oprawców, widząc słabość osadzonych, karcili ich, jednak byli też tacy, którzy współczuli i pomagali. O tego typu pomocy piszą Wanda Półtawska ${ }^{24}$ oraz Jadwiga Ankiewicz. Aufzejerki — kobiety pełniące służbę w nazistowskich obozach koncentracyjnych III Rzeszy, mające własne rodziny, wiedziały, jak wygląda życie więźniarek i wielokrotnie ostrzegały je przed nadchodzącym zagrożeniem. Pomagały im w zdobywaniu jedzenia lub kierowały do lżejszych prac. Nie zawsze jednak było to możliwe, gdyż same narażały przy tym własne życie. Aufzerjerkami zazwyczaj były więźniarki z obozów karnych, przestępczynie, które mimo to potrafiły okazać dobroć. One same czuły się wykluczone, zostały zesłane do obozu i każde złe posunięcie kończyło się dla nich karą. Pisze o tym Jadwiga Ankiewicz:

Po śniadaniu znów była ta dobra, czarna Niemka. Potem powiedziała nam, żebyśmy się nie martwiły, żebyśmy tylko były cierpliwe, a na pewno niedługo będziemy w domu. Ona także

${ }^{23}$ H. Rusek, op. cit., s. 69.

24 Wanda Półtawska - polska lekarka, doktor nauk medycznych oraz specjalista w dziedzinie psychiatrii, profesor nadzwyczajny Papieskiej Akademii Teologicznej, harcerka, podczas drugiej wojny światowej więziona w niemieckim obozie koncentracyjnym w Ravensbrück, dama Orderu Orła Białego. 
tęskni już za domem i chciałaby, żeby się to jak najprędzej skończyło. Z pewnym wahaniem wyjęła z portfela fotografię małego ślicznego chłopczyk. Pochyliła głowę, szepnęła: „mein Sohn” i ukradkiem wytarła oczy ${ }^{25}$.

W obozach koncentracyjnych każdy czegoś się bał. Mogła to być kara śmierci, skatowanie przez ludobójców. Nie było osoby, która umiała pogodzić się z losem, jaki ją spotkał.

Do pięknych chwil można zaliczyć momenty solidarności więźniów, między innymi w obozie w Ravensbrück, w którym poddawane nieludzkim eksperymentom pseudomedycznym kobiety zbuntowały się, pokazały, że wspólne działanie może uratować im życie. Walka o przetrwanie, o byt była szokiem dla oprawców. Nie pomagały zastraszenie, głód, a nawet prośby, również negocjacje nie przyniosły rozwiązania. Kobiety — nazywane ,królami”26 — wygrały 27.

\section{Izolacja narodów}

Istotną cechą obozów koncentracyjnych była ich wielonarodowość. Więźniowie zdawali sobie sprawę, że bez względu na to, jakiej kto jest narodowości, wszystkich czeka ten sam los, te same cierpienia. Starali się zatem pomagać sobie i współpracować mimo barier językowych. W komunikacji wspomagano się gestami, podobnymi słowami. Można tu przytoczyć wspomnienie Haliny Rusek:

Pamiętam, że pracowała z nami Żydówka greckiego pochodzenia, Flora. Mieszkała w naszym baraku, pracowała też w tym Weberei. Należała do najbiedniejszych Żydów, więc jak mogłyśmy, tak ją wspierałyśmy. Nauczyła się nawet kilku słów po polsku, żeby się do nas przymilić i coś od nas dostać ${ }^{28}$.

Każdy z więźniów przeczuwał swój los i dlatego też wzajemna pomoc, wsparcie były im tak potrzebne. Nie było ważne, z jakiego kraju pochodzili osadzeni, z jakiej części Europy, wszyscy walczyli o przetrwanie. Obóz stał się dla wielu domem, w którym wzajemne relacje okazywały się korzystne. Żyli tu ludzie o różnych charakterach i potrzebach. Grupą napiętnowaną w lagrze - i przez nazistów, i często przez innych więźniów - ze względu na swą narodowość byli Żydzi. Czuli się oni w związku z tym odizolowani, gorsi od innych. Częsta zazdrość o lepsze traktowanie, większe racje żywnościowe, a nawet o życie była powodem sprzeczek, walki, uszczypliwości oraz zdrady. Ideologia nazistowska miała na celu likwidację narodowości żydowskiej. Paragrafy aryjskie wyłączające z prawa do członkostwa w organizacjach osób nienależących do „rasy aryjskiej” były postulowane przez antysemitów i ustanowione w wielu organizacjach. To oni

25 J. Ankiewicz, op. cit., s. 61.

${ }^{26}$ Króle, czyli „króliki doświadczalne” — nazwa więźniarek poddawanych doświadczeniom medycznym w obozie w Ravensbrück.

27 W. Półtawska, op. cit., s. 143.

28 H. Rusek, op. cit., s. 74. 
od razu po przybyciu do obozu często byli kierowani do komory gazowej, to oni wraz z innymi więźniami musieli pozbyć się swojej biżuterii, ubioru, włosów. Została im odebrana nie tylko godność człowieka, ale też narodowa. Część Żydów przeżyła obóz. Założyli nowe rodziny, starali się usunąć z pamięci koszmar wojenny. Niestety wojna odcisnęła na nich trwałe piętno - nie potrafili oddzielić późniejszego życia od obozowych przeżyć.

Reasumując, wykluczenie ze świata obozowego nie było spowodowane wyłącznie niechęcią innych narodowości. Można powiedzieć, że wielu wykluczyło się samodzielnie lub byli zmuszeni do wykluczenia. Powodem mogła być niechęć do nawiązywania kontaktów z innymi więźniami lub współpraca z nazistami w obozie.

\section{Miłość a osamotnienie}

Ludzie w obozie w różny sposób uciekali od izolacji. Tęsknota za miłością, dotykiem innego człowieka, czułością i uśmiechem miała różne oblicza. Czytamy:

Bywały krótkie, mało znaczące spięcia... i bywały prawdziwe, serdeczne, tkliwe uczucia, podsycane stale czyhającym niebezpieczeństwem, wypływające z potrzeby troszczenia się o kogoś i z potrzeby opieki, pokrzepienia, otuchy, silnego męskiego ramienia, z potrzeby usłyszenia tych kilku słów: „Nie bój się maleńka, będzie dobrze, przytul się do mnie”29.

W wielu przypadkach była to miłość platoniczna, wyrażana w listach, we wspólnych marzeniach o przyszłości. Niepozorne, lecz niebezpieczne spotkania więźniów, przekazywanie krótkich wyznań miłosnych miało na celu odzwierciedlenie czasów przedwojennych, kiedy to spotkania miłosne wpisane były w życie codzienne. Kobiety w obozie często wstydziły się swojego stroju, urody, wyniszczenia organizmu, braku włosów. Nic nie odróżniało ich od innych. Jednak mimo wszystko liczyły na gesty życzliwości, między innymi od więźniów współdzielących niewolę. Wiele $\mathrm{z}$ tych kobiet, odartych z człowieczeństwa, wynędzniałych i złamanych moralnie, zmuszonych było do pracy w domach publicznych „puffach” ${ }^{30}$, w których służyły za obiekty seksualne swoim oprawcom lub też „wzorowym więźniom”. Często żyły w przeświadczeniu, że daje im to gwarancję przeżycia lagru, nie doświadczały współczucia innych współwięźniarek. Traktowane były z obrzydzeniem, wyszydzano je. Trudno ich nie zrozumieć, chciały poczuć się potrzebne, żyć w luksusie, w jakim wcześniej przebywały. Ciało ludzkie stało się dla nich bezwartościowe. Marzenie o dobrobycie przybrało formę bezmyślnego uwolnienia się od codziennej tragedii.

W obozach koncentracyjnych jako przestrzeni izolacji więźniów pojawiło się także innego typu pożądanie, miłość o zabarwieniu homoseksualnym. W wielu dokumentach obozowych można spotkać krótkie opisy takiej miłości. Theresa

29 K. Żywulska, op. cit., s. 231.

30 Puff — dom publiczny w obozie koncentracyjnym. 
Kaminski twierdzi, że ,jedną ze strategii przetrwania jest stworzenie kategorii »dobrej kobiecości«, która wyróżnia i tym samym ochrania kobiety przetrzymywane w ekstremalnie trudnych warunkach" ${ }^{1}$. Ta „dobra kobiecość” ujawniała się w obozach w grupach jednorodnych płciowo. Nierzadko aufzejerki zmuszały kobiety do tej miłości. Zachęcały je do spotkań, kusząc lepszymi porcjami żywnościowymi, błyskotkami. Wymagania stawiane przez nadzorczynie często były nie do przyjęcia, ale głód i nędza sprzyjały takim rozwiązaniom. Skazane decydowały się na poniżenie, do którego w normalnym życiu nigdy by nie dopuściły. W wielu przypadkach nie miały innego wyboru. Decydującym czynnikiem było przeżycie, opuszczenie lagru. Spotkania o podłożu seksualnym miały odczłowieczyć więźniów, sprowadzić ich do roli zwierząt. Sami oprawcy również w nich uczestniczyli, często także zakochiwali się w więźniarkach. Przeszkody etyczne nie były dla nich żadnym problemem. O upodleniu ludzi pisze Wanda Półtawska:

Z obozu wyniosłyśmy wstręt do kobiet i przesadny ideał mężczyzny, dawno nie widzianego, a teraz ci wszyscy, których spotkałyśmy, patrzyli na nas tak, że czułyśmy się tym obrażone i bałyśmy się ich... ${ }^{32}$

Walka o byt w obozie koncentracyjnym przybierała różne formy. Jednym ze sposobów ucieczki więźniów od izolacji, niepoddawania się wyobcowaniu była wiara, miłość do Boga. W lagrze krzyżowały się różne odłamy religijne, różne wyznania. Wiara miała wpływ na życie codzienne, na pozbywanie się myśli samobójczych, na walkę o przetrwanie. Uroczystości religijne, śpiewy oraz modlitwy uspokajały więźniów. Najprostsze słowa otuchy miały znaczenie. Osoby wierzącej nie można odizolować od Boga, chyba że sama tego chce. Zbrodniarze nie zdawali sobie sprawy, że nie są w stanie zniszczyć wśród więźniów wiary. Śpiewy w obozie, zamiast dzielić — na co liczyli oprawcy, łączyły ludzi z sobą. Stawali się mocniejsi duchem, chociaż często brakowało im sił, to jednak wiara powodowała, że każdy z więźniów żył nadzieją na lepszą przyszłość.

\section{Skutki izolacji}

Izolacja wśród więźniów była nie do zniesienia. Doprowadzała do wynaturzenia ludzi. Więźniowie często wpadali $\mathrm{w}$ depresję, nie umieli poradzić sobie z własnymi problemami. Skutkiem izolacji była trauma objawiająca się w już obozie, a potem na wolności. Choroby psychiczne, zniszczenie osobowości miały ogromny wpływ na późniejsze życie. Jak wyjaśnia Tadeusz Łysak: „Trauma wskazuje na rozdzierające pęknięcie lub cezurę doświadczenia, którego efekty

31 T. Kaminski, Prisoners in Paradise: American Women in Wartime South Pacific, Lawrence 2000 .

32 W. Półtawska, op. cit., s. 185. 
pojawiają się po pewnym czasie"33. Następuje odgrywanie, analizowanie swojej przeszłości. Często więźniowie godzili się ze swoimi traumatycznymi przeżyciami i ich symptomatycznymi skutkami. „Traumę można zrozumieć na wiele sposobów. Ułomność czy konieczność błądzenia w mroku są nie do uniknięcia" ${ }^{34}$. Trzeba próbować zrozumieć to, co ludzie przeżyli w lagrze.

Byli więźniowie często cierpieli na zespół obozu koncentracyjnego. Jest to poważne zaburzenie cechujące się przewlekłym przebiegiem. Stanowi wynik ogromnego stresu i urazu psychicznego. Jak twierdzi psychiatra Krzysztof Rutkowski ${ }^{35}$, symptomy mają różny charakter - przykładowo część więźniów ukrywała się przed bliskimi, nie chciała z nikim rozmawiać o przeszłości. Odczuć można było chłodne traktowanie innych ludzi. Byli osadzeni odtwarzali swój uraz w formie uporczywie nawracających wspomnień, przez przesadne gromadzenie różnych rzeczy, strach przed ludźmi noszących mundury, na przykład listonoszem. Tego typu zachowania wiązały się z poczuciem zagrożenia życia czy opresji. Inny symptom lękowy to pobudzenie byłych więźniów, na przykład na sygnał dzwonka. Często nie umieli przystosować się do nowego życia, mówili, że są teraz innymi ludźmi, że nie potrafią być tacy jak przed wojną. W obozach zmieniała się ich osobowość, niekiedy wzmacniał się charakter. Byli więźniowie często także ukrywali swoje wnętrze przed innymi, bardzo dobrze się maskowali, kontrolując swoje zachowanie. Choroba nierzadko pojawiała się dopiero po latach. Osoba z zespołem obozowym mogła mieć problemy z wypoczynkiem, nie umiała wykorzystać czasu na regenerację. W procesach starzenia się organizmu dochodziło do nasilenia się różnego typu symptomów. Często byli więźniowie nie umieli zaakceptować samych siebie ani ułożyć sobie życia ze swoimi bliskimi.

Antoni Kępiński ${ }^{36}$ obawiał się ingerować w świat przeżyć więźniów. Trauma powodowała, że ludzie z niechęcią wspominali przeszłość. Trzeba pamiętać, że w obozach przebywali więźniowie różnych profesji. Byli tam także żołnierze, akowcy, którzy po wojnie bali się opowiadać o swoich przeżyciach, często poddawano ich prześladowaniom.

Po wojnie zaobserwowano również postawę zwaną „sylwetką ocalonego"37. Dotyczy ona przede wszystkim osób, które nigdy nie były w obozie i miały wyrzuty sumienia z powodu swego ocalenia. Były to jednostki społecznie wycofane.

33 T. Łysak, Kryzys objaśniania. Trauma wojenna a teoria psychoanalityczna, Kraków 2006, s. 361 .

34 T. Łysak, op. cit., s. 368.

35 Krzysztof Rutkowski - profesor, psychiatra z Katedry Psychoterapii Uniwersytetu Jagiellońskiego Collegium Medicum.

36 Antoni Kępiński (1918-1972) — profesor, polski lekarz, psychiatra, naukowiec, humanista i filozof.

37 Syndrom obozowy mógł latami trwać uśpiony w psychice więźnia, rozmowa R. Jurszo z prof. Krzysztofem Rutkowskim, https://www.mp.pl/pacjent/psychiatria/aktualnosci/136620,syndrom-obozowy-mogl-lallatami-trwac-uspiony-w-psychice-wieznia (dostęp: 27.01.2016). 


\section{Odosobnienie rodzinne}

Interesującym zagadnieniem $\mathrm{w}$ kontekście kwestii izolacji staje się temat dotyczący dzieci w obozach. Najczęściej nie miały one świadomości, że albo zostaną zamordowane wraz z rodzicami tuż po przybyciu do lagru, w komorach gazowych, albo umrą trochę później, na skutek ciężkich obozowych warunków, głodu i chorób. Uśmiechnięte, beztroskie dzieci początkowo nie odczuwały strachu ani wykluczenia, nie rozumiały też sytuacji, w jakiej się znalazły. Należy tu zasygnalizować olbrzymi ból, cierpienie i tęsknotę matek, których dzieci już zginęły, obserwujących inne dzieci, przybywające do obozu. Z kolei dzieci, które przebywały już w obozie, niejednokrotnie widziały swoje matki oraz ojców idących do krematorium, starały się ich dogonić. Ból, jaki im towarzyszył, nie pozwalał im potem zapomnieć o rodzicach. Inni skazani po jakimś czasie przestali zauważać borykające się ze swoimi problemami i z nagłą utratą rodziców dzieci. Rozpacz wynikająca z samotności była oznaką zamknięcia w sobie własnych uczuć. Wyparcie miłości rodzicielskiej było pozbawione sensu. W wielu przypadkach dzieci, które rodziły się w obozie, odbierano matkom zaraz po porodzie i wywożono w głąb Niemiec, aby tam zostały wychowane na ,prawdziwych” Niemców; dotyczyło to też dzieci uważanych za „aryjskie”. Miało to na celu powolne wyniszczanie niepotrzebnej rasy, a także pozbawienie wartości macierzyńskich. Halina Rusek wspomina:

Trzeciego dnia weszło do celi kilku gestapowców w celu odłączenia dzieci. Działy się dantejskie sceny. Matki rzucały się do stóp gestapowców, błagając, aby nie zabierano im dzieci. Niemcy kopali, bili pejczami i wydzierali z rąk nieprzytomnych matek przeraźliwie płaczące dzieci ${ }^{38}$.

Kobiety, którym odebrano dzieci, zdawały sobie sprawę, że ich los zależy od oprawców, ale miały także nadzieję na dobre wychowanie dzieci przez obce rodziny oraz na odzyskanie z nimi kontaktu w przyszłości, że do całkowitej izolacji, zerwania więzów rodzicielskich nie dojdzie.

$* * *$

Omawiając temat izolacji, odniosłem się do historycznych skutków wpływu wydarzeń na psychikę ludzką. Druga wojna światowa jak wszystkie inne wojny i konflikty zbrojne cechowała się wyniszczeniem ludzi, mogła doprowadzić do niewyobrażalnych negatywnych skutków wywołanych przez władzę dążącą do zwycięstwa. W każdej wojnie w uproszczonym rozumieniu są zwycięzcy i przegrani. Nasuwa się pytanie, kto jest zwycięzcą. Jedynie grupy rządzące. Wszyscy są na przegranej pozycji, ponieważ nie ma takiej osoby podczas konfliktu zbrojnego, która nie straciłaby w nim kogoś bliskiego czy nie ucierpiałaby

38 H. Rusek, op. cit., s. 47. 
w inny sposób. Wojna dotyka wszystkich. W szelkie analizy naukowe wykazują, że izolacja wojenna doprowadziła do spustoszenia psychiki. Trauma obozowa ludzi ocalonych narzuca pewien schemat myślowy. Ludzkość zaczęła się zastanawiać nad istotą wojny, kryzys zbrojny nie przyniósł nikomu niczego dobrego, wręcz przeciwnie - ukazał społeczeństwom nieustanną walkę o byt. Może dlatego żyjmy nadzieją, że mimo wszystko dobro zwycięża i że nawet przebywając w izolacji, nie jesteśmy samotni.

\section{Bibliografia}

Ankiewicz J., Majdanek. 15.01-17.05.43 r. Dziennik, red. J. Laskowska, Lublin 2020.

Dauksza A., Klub Auschwitz, Kraków 2021.

Glińska A., Moralność więźniów Oświęcimia, „Etyka” 2, 1967.

„,Gtosy z Ostatniego kręgu”. Korespondencja z Konzentrationslager Auschwitz Józefa Kreta i Zofii Hoszowskiej Kretowej, oprac. K. Heska-Kwaśniewicz, L. Sadzikowska, Katowice 2020.

Iwasiów I., Centralna płeć cywila, [w:] Wojna. Doświadczenie i zapis - nowe źródła, problemy, metody badawcze, red. S. Buryła, P. Rodak, Kraków 2006.

Kaminski T., Prisoners in Paradise: American Women in Wartime South Pacific, Lawrence 2000.

Łysak T., Kryzys objaśniania. Trauma wojenna a teoria psychoanalityczna, [w:] Wojna. Doświadczenie i zapis - nowe źródta, problemy, metody badawcze, red. S. Buryła, P. Rodak, Kraków 2006.

Nancy J.-L., Rozdzielona wspólnota, przeł. M. Gurin, Wrocław 2010.

Pawełczyńska A., Wartości a przemoc. Zarys socjologicznej problematyki Oświęcimia, Warszawa 1995.

Półtawska W., I boję się snów, Częstochowa 1998.

Rodak P., Dziennik osobisty jako praktyka piśmienna: działanie, materialność, tekst, [w:] Antropologia pisma od teorii do praktyki, red. P. Atrieres, P. Rodak, Warszawa 2010.

Rusek H., Koleżanki z Birkenau. Esej o pamiętaniu, Katowice 2019.

Ryn S., Kłodziński S., Postawy i czyny heroiczne w obozach koncentracyjnych, „Przegląd Lekarski — Oświęcim" 1986, nr 1.

Sadzikowska L., Listy z lagrów i więzień 1939-1945. Wybrane zagadnienia, Katowice 2019.

Sadzikowska L., Ludobójstwo w świetle wybranych relacji więźniów obozów koncentracyjnych Auschwitz, Majdanek, Stutthofi Gross-Rosen, „Narracje o Zagładzie” 2020, nr 6.

Syndrom obozowy mógł latami trwać uśpiony w psychice więźnia, rozmowa R. Jurszo z K. Rutkowskim, https://www.mp.pl/pacjent/psychiatria/aktualnosci/136620,syndrom-obozowy-mogl-lallatami-trwac-uspiony-w-psychice-wieznia.

Wiem, jak wygląda piekto. Alina Dąbrowska w rozmowie z Wiktorem Krajewskim, Warszawa 2019. Wiszniewska I., Tajemnica rodzinna z Żydami w tle, Warszawa 2020.

Żywulska K., Przeżyłam Oświęcim, Warszawa 2004.

\section{Isolation and the concentration camp: Prolegomena}

\section{Summary}

Everyone is created to live in a herd, a group of people with whom they build a community. The community may be the family home, friends, acquaintances from work, the backyard or even the street. We feel better when we meet other people. 
When modern man speaks of isolation, he thinks only of closing himself off at home, peace and quiet, lack of contact with his family or going off into the unknown.

He does not think of the forced isolation that prevailed among people in wartime. It determined everyday life, changed people's values and dehumanised them. The worst was the camp isolation, which took people by surprise. No one expected that someone could deprive people of their lives, away from family and friends.

Isolation can be divided into sectors: internal and external. With time it is possible to get out of it. A person's attitude and the presence of other helpful people can help. People in the camp escaped isolation in different ways. The longing for love, the touch of another human being, tenderness and a smile had different faces.

One of the themes of camp life was children going to slaughter. They did not realise that they would disappear from the face of the earth together with their parents. Smiling, carefree children were not afraid of anything, they felt no fear or exclusion.

International cooperation was the order of the day in many camps. Although the women did not know the language, they used gestures, similar expressions. Each of the women prisoners sensed their fate and therefore needed each other's help. No matter what country the prisoners came from, no matter what part of Europe, they all fought to survive. For many of them the camp became a home, where relationships proved beneficial.

The escape from camp "happiness" was all-day work outside the camp. Prisoners would go out on purpose to do hard work in the fields, digging pits, in order not to see what was going on in the camp.

The variety of isolation is beyond comparison. It is possible to live in isolation, to have contact with others, but to be well aware that one day normality will return. The people in the camp also had hope, but they knew that this hope could end rather quickly for them - in the crematorium.

Keywords: concentration camp, prisoner, memory, suffering, isolation 